Soci o- Econom c Activiti es of For mer Feudal Lords i $n$ the Mei i Japan

\begin{tabular}{|l|l|}
\hline 著者 & Abe Takeshi, Shi rai I zum, Yuki Takenobu \\
\hline $\begin{array}{l}\text { j our nal or } \\
\text { publ i cat } \mathrm{i} \text { on } \mathrm{t} \text { i t I e }\end{array}$ & TERG Di scussi on Paper s \\
\hline number & 373 \\
\hline page range & $1-27$ \\
\hline year & $2017-08$ \\
\hline URL & ht t p: //hdl . handl e. net /10097/00121964 \\
\hline
\end{tabular}




\section{$\mathbb{T} \mathbb{E} \mathbb{R} \mathbb{G}$}

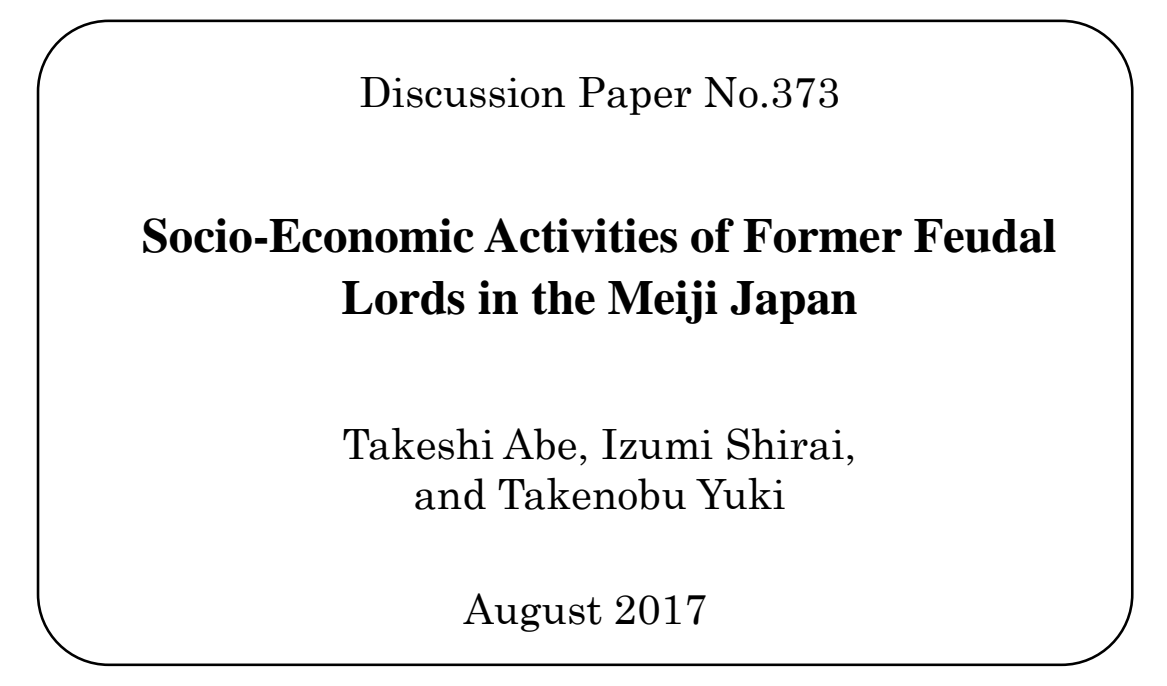

\section{TOHOKU ECONOMICS RESEARCH GROUP \\ Discussion Paper}

GRADUATE SCHOOL OF ECONOMICS AND MANAGEMENT TOHOKU UNIVERSITY 27-1 KAWAUCHI, AOBA-KU, SENDAI, 980-8576 JAPAN 


\title{
Socio-Economic Activities of Former Feudal Lords in the Meiji Japan
}

\author{
Takeshi Abe ${ }^{\text {a*}}$, Izumi Shirai ${ }^{\mathrm{b}}$, \\ and Takenobu Yuki
}

${ }^{a}$ Faculty of Political Science and Economics, Kokushikan University, Tokyo, Japan;

${ }^{b}$ Japan Business History Institute, Tokyo, Japan; ${ }^{c}$ Graduate School of Economics, Tohoku University, Sendai, Japan

*abetk@kokushikan.ac.jp

\begin{abstract}
In the early phase of Japan's industrialization after 1886, the upper class of ex-samurai, known as daimyo with huge assets, played an important role as pioneers in equity investments in modern industries. Furthermore, when their ex-retainers founded modern enterprises, daimyo often invested in their businesses. In addition, daimyo often created opportunities for the education of young people in their former fiefs. After explaining the daimyo in the Meiji period, this article first elucidates how daimyo promoted equity investments in modern industries. Second, this study analyses the socio-economic activities of one of the main daimyo, Tsugaru Tsuguakira in Tsugaru region.
\end{abstract}

\section{Keywords}

Meiji Period, daimyo, kazoku, peerage, noblemen, industrialization, modern enterprise, equity investment, Tsugaru Tsuguakira, Tsugaru region, education investment, human capital 


\section{Socio-Economic Activities of Former Feudal Lords in the Meiji Japan}

\section{Introduction}

The Meiji Era (1868-1911) was the age of Japan's so-called 'Rich Nation, Strong Army', in which the nation succeeded at being the first Asian country industrialized, and became one of the military powers in the world through victories during the Sino-Japanese War (1894-1895) and the Russo-Japanese War (1904-1905).

However, Japan's path to industrialization success, which is the topic of our interest, was a little complicated. In about the first decade of the Meiji period, the government made great efforts to foster modern manufacturing industries, such as cotton spinning, sugar refining, beer brewing, coal or copper mining supported by Western technology, the new transport system by founding and managing railroads, and defence. In addition, the government allowed wealthy families, such as the Mitsuis and Iwasakis (Mitsubishi), to establish a bank and a shipping company, respectively. ${ }^{1}$ However, except for the prosperity of the national banks, which were joint stock companies and could issue inconvertible notes after 1876, the results of the government's efforts were not fruitful.

In 1881-1885, the then Finance Minister, Matsukata Masayoshi (1835-1924), rebuilt government finances, after the state had once become bankrupt because of inflation. Matsukata newly established the Bank of Japan, which was the only bank that could issue silver conversion notes, while the system of national banks was abolished thereafter. Through Matsukata's reform, fiscal policy and monetary policy, which had been blended together, became clearly divided, and both were modernized. ${ }^{2}$

In 1886, once this reform was complete, an enterprise boom developed and many private companies emerged, mainly in rail and cotton spinning. Japan's industrialization started at this time. During almost the same period, most government enterprises were sold to common people, some of whom, like the Mitsuis, Mitsubishis, Sumitomos, Fujitas, Furukawas, Asanos, and Okuras, developed as zaibatsu. Such family businesses also came to promote industrialization. ${ }^{3}$

Why did the government's industrial policies in this period fail? Why could private enterprises but not the government realize industrialization? These questions are very important to understand the characteristics of Japan's industrialization.

The heritage of the Tokugawa period (1603-1868) in the Meiji Period was as follows. (1) The newly established government was supported by excellent bureaucrats, whom the Tokugawa regime had nourished. For example, Enomoto Takeaki (1836-1908), a famous admiral of the Tokugawa navy who had resisted the new Meiji government at Hakodate in Hokkaido until 1869, negotiated with Russia as the ambassador extraordinary and 
plenipotentiary of the government in 1874, and concluded the Treaty of Saint Petersburg in the following year. (2) The strong development of private financial businesses in the Tokugawa period helped the smooth introduction of the modern banking system. ${ }^{4}$ (3) Commerce and industry developed significantly in the rural areas, where the market economy penetrated even better than in urban areas. ${ }^{5}$ (4) The number of wealthy families increased, and entrepreneurs appeared from the stratum as time passed. ${ }^{6}$ Finally, (5) the average level of literacy of the Japanese population was very high during the Tokugawa period. $^{7}$

We return to the abovementioned questions. We can guess that, before the reliability of the economic policies of the Meiji government were established by Matsukata through the modernization of the fiscal and monetary system, private entrepreneurs, who already existed in the early Meiji period, showed negative attitudes toward investment in unknown modern businesses, especially joint stock companies, in which they collaborated with unspecified large numbers of shareholders. This was despite the government's strong recommendation of such companies. Incidentally, investment in national banks was an exception, because high returns were apparently expected from such investment.

In such circumstances, the upper class of ex-samurai, the daimyo, most of whom came to own huge assets in the 1870 s, played the important role of pioneering equity investments in modern industries, guided by the leadership of key individuals, such as Iwakura Tomomi (1825-1883), the political leader of kugyo (traditional noblemen), and Shibusawa Ei'ichi (1840-1931), the founder of many modern business enterprises and economic organizations, as we explain in Section 2.1..

Furthermore, although daimyo, started to live in Tokyo after the establishment of prefectures by government order in 1871 instead of han, the feudal domain in which daimyo had been administered, most of them kept in touch with the local people in their old han, both socially and economically. When their ex-retainers founded banks and/or cotton spinning enterprises, daimyo often invested in these businesses. Apparently, daimyo were one of the pillars of Japan's early industrialization. In addition, daimyo often created opportunities for the education of young people in their former fiefs, providing them with funds for higher education, and making great efforts to foster human capital. Such activities indirectly contributed to Japan's industrialization.

This study first elucidates how daimyo promoted equity investments in modern industries, mainly in enterprise booms in the mid- and late-Meiji period. Second, this study analyses the socio-economic activities of one of the main daimyo, Tsugaru Tsuguakira, whose former han was located in Tsugaru region in modern-day Aomori 
prefecture. We first explain the daimyo in the Meiji period in the next section before proceeding to answer the abovementioned two research questions.

\section{Characteristics of Daimyo Class in Meiji Period}

\section{Transformation of Daimyo during the Meiji Restoration ${ }^{8}$}

In the Tokugawa period, kugyo and even the Japanese Emperor (Tenno ) were kept away from power, and lived rather poorly and quietly, while the samurai class, whose status was formally much lower than that of the kugyo, continued to rule Japan politically. The upper class of samurai, which was consigned wide land of more than $10,000 k o k u^{9}$ by the Tokugawa regime were called daimyo, and they numbered about 300. However, daimyo never owned these vast fiefs themselves. The power of the daimyo was confined by the Tokugawa regime, which often obliged daimyo to move to another han.

This situation changed drastically in the Meiji Restoration around 1868, when the Tokugawa regime collapsed and the samurai class started declining. On the other hand, the newly established Meiji government let the emperor be the supreme authority instead of the Tokugawa shogun, and, therefore, the social status of kugyo rose remarkably.

In July 1869, hanseki hokan, the return of the land and people from daimyo to the emperor, was implemented. A daimyo was newly nominated as a governor of his old han, where he used to be a kind of administrator, and was guaranteed not only 10 percent of the annual tax revenue in the han as karoku (salary for the family) but also shotenroku (an additional salary, which was newly set up as reward for the civil war of 1868-1869). Most daimyo were saved by these new salaries, and on the whole, came to possess greater wealth than before. ${ }^{10}$ Meanwhile, the ordinary ex-samurai in han, namely, the exretainers of the daimyo, often had drastic cuts to their karoku, and became poorer during the turmoil of the Meiji Restoration. The main daimyo during the Hanseki Hokan are shown in Table 1.

[Table 1 near hear]

Simultaneously, in the same July 1869 a new peerage class, kazoku, was created by the Meiji government, which comprised not only kugyo but also the daimyo as members of kazoku. This class existed until 1947. On the other hand, ordinary samurai were incorporated into the newly established shizoku (ex-samurai) class.

After, haihan chiken, the establishment of prefectures in place of han in August 1871, the Meiji government inherited not only land but also people and debt from every han. The salaries of the ex-samurai were also inherited by the new government, which 
proceeded to cut them drastically. Nevertheless, the payment of their salaries came to drain the government budget. For example, in around 1876, the salaries amounted to 36 percent of the general account budget, leading the government to intend to further reduce these payments for the ex-samurai. In November 1873, the government established a tax on karoku, and in the following month, the government promulgated rules on retaining the right to receive a salary. By this ordinance, an applicant could obtain 6 years' salary if he originally had a hereditary salary, or 4 years' salary if he originally had a lifetime salary. In both cases, half the salary was paid in cash, while the rest was paid by government bond, chitsuroku kosai, with an interest rate of 8 percent. This formal policy was intended to allow the ex-samurai class to move into agriculture, industry, and commerce. In 1871, daimyo finally lost their ruling power over land from the abolishment of han. Thereafter, some daimyo individually invested in land in the former han as modern real estate. Nevertheless, not all the peers had land, and European-type peers with vast land were rather rare in modern Japan.

Even after 1873, when the land tax reform (chiso kaisei) started, rice was handed to the ex-samurai as payment in kind. However, in 1875, cash salary (kinroku ) at an annual average price of karoku for 3 years became the new method for paying wages. In 1876, the government promulgated the kinroku kosai shosho hakko jorei, which stipulated that payment of cash salaries to the ex-samurai class would be abolished (chitsuroku shobun), and huge government bonds would be issued instead from 1877. The funds for the bonds were borrowed from the West. Thereafter, most ex-samurai became poorer; the lower class received only one-third of the minimum daily wage of a construction worker in Tokyo. In addition, many ex-Samurai sold their bonds; about 90 percent of the ex-samurai in Tottori prefecture had sold their bonds by 1882. Although the government promoted jobs for ex-samurai, such as soldiers for the defence and development of Hokkaido, it was very difficult to force ex-Samurai to do so, and they often rioted against the Meiji government. For example, there were riots in 1874 at Saga; in 1876 at Kumamoto, Akizuki in Fukuoka prefecture, and Hagi in Yamaguchi prefecture; and in 1977 in wide areas in Kyushu (Seinan senso ) around Kagoshima prefecture. On the contrary, many former feudal lords obtained huge amounts of bonds, which they could not freely sell.

\section{Influence of New Peerage on Daimyo}

Daimyo as well as kugyo became the members of kazoku, the new peerage established in 1869. How did this reform influence the daimyo? To understand it, we explain the imperial statement about kazoku in November 1871 and the newly promulgated kazokurei in 1884. 
The imperial statement in 1871 gave a great deal of public attention to kazoku, which the emperor expected to serve as a model for Japanese people. According to the statement, kazoku should learn with diligence in order to allow the nation to develop, and should also study abroad. Moreover, the emperor recommended that women in kazoku families go abroad with their husbands or brothers, so as to learn the methods of childcare in foreign countries. ${ }^{11}$ In summary, kazoku were expected to form an intellectual or welleducated social class in modernizing Japan by the political leaders of the early Meiji period, who used the young 19-year-old emperor to achieve their ends. Incidentally, Tsugaru Tsuguakira, whose social activities we scrutinize in Section 3, started to learn English in earnest from January 1872, just after the release of the imperial statement. ${ }^{12}$

What occupations did kazoku aim to fill? In general, male kazoku and their sons hoped to become, for example, statesmen, commissioned military officers, and diplomats. On the other hand, their daughters desired to become good wives and wise mothers. It was good for their daughters to get married to a nice man of kazoku standing, to give birth, and to care for their children. Children of kazoku were guaranteed the right to education at Gakushuin, established in 1877 as a school for kazoku by the Imperial Household and kazoku. The Gakushuin had a kindergarten as well as elementary and middle schools. For male students, the importance of military and physical education was emphasized. ${ }^{13}$ From these facts, we find that male kazoku were required to play important roles in the field of military and politics, but not business.

In 1884, an ordinance on peers, kazoku-rei, was promulgated by the Ministry of the Imperial Household, thereby establishing a new peerage system by which all Japanese noblemen were classified into five ranks with the following titles: prince (koshaku), marquis (koshaku), ${ }^{14}$ count (hakushaku), viscount (shishaku), and baron (danshaku). The new peers (shin-kazoku) were created in addition to the traditional old peers (kyu kazoku, consisting of kugyo and daimyo). The new peers included the following two groups: first, famous priests of Buddhism and Shinto, and second, various private citizens who had achieved prominence after the Meiji Restoration in various fields, such as politics, public administration, business, and academic research. The new peers, who were not born noblemen, included such businessmen as Iwasaki Hisaya and Iwasaki Yanosuke, the founders of the Mitsubishi zaibatsu (both were ennobled in 1896), Shibusawa Eiichi, a great organizer of Japanese businesses, as mentioned in Introduction (1900), Konoike Zen'emon, a famous financier in Osaka since the Tokugawa period (1911), Kondo Renpei, President of Nippon Yusen Kaisha in the Mitsubishi zaibatsu (1911), Sumitomo Kichizaemon of the Sumitomo zaibatsu (1911), Fujita Denzaburo of the Fujita zaibatsu (1911), and Mitsui Hachirojiro of the Mitsui zaibatsu (1911), most of whom were known 
as the heads of their zaibatsu families, and were nominated as barons after the SinoJapanese War. ${ }^{15}$

The government' political purpose after the political crisis in October 1881 apparently became to establish a Prussian-style 'Strong Army and Rich Nation' ruled by the grand emperor, Meiji Tenno, against the Free Civil Right Movement that had been active since 1874, and the reorganized peer class was expected to help enforce this goal and to protect Tenno and his family. After the promulgation of the Meiji Constitution in February 1889, the House of Commons and the House of Peers were founded. While the 30year-old princes and marquises automatically became members of the House of Peers, the rest representatives of three lower classes of kazoku in the same house were elected by mutual vote. It is important that kazoku were deemed the protectors of the royal family (koshitsu no hanpei ), and were obliged to strictly restrain from speculative activities. ${ }^{16}$

Kazoku-rei was revised in 1907, and promulgated by the Imperial Household itself. The new ordinance stated the regulations to kazoku's social behaviour. In particular, the new kazoku-rei stated that those who could not retain their dignity would no longer be treated as kazoku, and their behaviour was monitored by the Ministry of the Imperial Household. ${ }^{17}$

In this way, it became difficult for kazoku, including the daimyo, to play active roles at the forefront of business, as time went on. However, as we see in Section 2.1., at least in the late 19th century, the former feudal lords contributed significantly to socioeconomic development as investors in the early stage of Japan's industrialization, and fostered human capital in their old han.

\section{Equity Investments by Daimyo Class}

\section{Significance of Equity Investment by Daimyo}

In this subsection, we consider how equity investment by the daimyo influenced the emergence of modern enterprises at the beginning of Japan's industrialization.

According to previous research, ${ }^{18}$ kazoku, including the daimyo, held passive equity investment, resulting from activities as rentiers, while merchants invested actively in equities and contributed to the establishment of companies and their management. However, such a view seems to have some problems.

First, there were less than 300 daimyo, and they have been thought of as the richest privilege class in the Meiji period. However, even before industrialization, some daimyo had invested actively in the equities of famous companies, such as the Fifteenth National Bank (established in 1877), Japan Railway Company (1881) in response to Tomomi Iwakura's order, ${ }^{19}$ and Tokio Marine Assurance Company (1879) and Osaka Spinning 
Company (1882) in response to the recommendation of Shibusawa Eiichi. ${ }^{20}$ The total sum of the equity investments of the daimyo was huge, and played a very important role in fund-raising for Japan's newly emerging companies after $1886 .{ }^{21}$ Although such roles tended to decrease in the development of Japan's economy, as before, the daimyo has continued to invest in many companies in various industries.

Case studies of the investments of individual daimyo have not been provided sufficiently in the previous research. However, some recent historians have started to provide such case studies. For example, the Kikkawa family of Iwakuni han, located in present-day Yamaguchi prefecture, established a family constitution that systematized the rules of the family, and showed how to administer and maintain its property. The family diversified its investments; the family classified its assets into movable property and real estate, and invested not only in banks and railways, as many researchers have mentioned, but also in manufacturing. ${ }^{22}$

Finally, although the business activities of the daimyo were formally those of an heir of a house, the real administration was usually conducted by their stewards, called kafu or karei, most of whom were the top leaders of former retainers. A good example is the Tachibana family in Yanagawa region in present-day Fukuoka prefecture, whose stewards actually made investment decisions, even after the establishment of the family constitution. $^{23}$

As mentioned earlier section, Kazoku, including the daimyo, were constrained from conducting such speculative and dangerous business activities that disgraced their family names by kazoku-rei, and were expected to maintain their dignity. Some kazoku, who could not bear to maintain such a heavy role, returned their noble titles, ${ }^{24}$ while others who could make better investment decisions survived persistently until 1947, when the peerage system collapsed by the new National Constitution. ${ }^{25}$ As mentioned section, the business activities of kazoku strongly influenced the founding of companies and their management in Meiji era.

\section{Position of Daimyo in Equity Investment}

What were the investment activities of daimyo? Tables 2 and 3 rank the top 100 shareholders in 1897 and 1907.

[Table 2 and Table 3 near here]

In 1897, the listed 331 firms had 1,956 shareholders in total and 2,224,115 shares. The top 100 largest shareholders owned 1,534,174 shares, or 68.9 percent of all shares. 
Toshitsugu Maeda, Tadayoshi Shimazu, and Nagakoto Asano, who were famous noblemen, ranked sixth, eighth, and ninth as top shareholders, respectively. Within the top 50, there were 11 peers, and within the top 100, there were 26 noblemen. The peers owned 253,746 shares, or 11 percent of all shares. Thus, they played an extremely important role in the development of the financial aspects of firms in the late 19th century. An important characteristic is that Sinobu Tajima, Steward of the Mori family, Kaneaki Hayakawa, Steward of the Shimazu family, Nagamasa Tanaka, Steward of the Nabeshima family, and Nagatoshi Inai, Steward of the Hachisuka family, were also major shareholders.

In 1907, the numbers of the firms and shareholders were 1,374 and 4,051, respectively. The total number of shares was 4,839,065. The top 100 largest shareholders owned 2,628,663 shares, or 54.3 percent of all shares. However, no daimyo was included in the top 10, and even Maeda Toshinari, the top-class daimyo, ranked 25th. Only 4 and 8 of the daimyo ranked within the top 50 and the top 100, respectively. All the peers owned 103,682 shares, or 2.1 per cent of the total shares. The ranking of the daimyo as the major shareholders dropped significantly. Thus, their position in equity investment fell, but some continued to be major shareholders, which suggested that a portion of the peers increased their profits by investing in stocks in the early 20 th century.

[Table 4 and Table 5 near here]

Tables 4 and 5 show the main kazoku, who undertook significant equity investment in 1897 and 1907, respectively. They invested not only in the Fifteenth Bank and Japan Railway Company, but also in other banks and railway companies as well as local businesses. In the next subsection, we introduce two case studies on asset management among the daimyo.

\section{Two Case Studies on Asset Management of Daimyo}

We select two cases: the Shimazu families, who ranked 8th, 47th, and 73rd in 1897 in Table 2, and 57th in about 1907, and the Kikkawa Family, who ranked 92nd in Table 3.

[Table 6 near here]

Table 6 shows the revenue structure of the Shimazu family, whose percentage of equities was 93.1 percent in 1885 , and 73.4 percent in 1892 . The Shimazu family apparently obtained most of its revenue from equity investment. The family started 
businesses by using funds earned in the $1890 \mathrm{~s}^{26}$

[Table 7 near here]

Table 7 shows the revenue structure of the Kikkawa family. In the first half of the 1890s, bonds, equities, and land occupied around 25 percent of total revenue, which seem competitive. However, in 1895, the proportion of equities (34.1 percent) was prominent, and it continued to increase thereafter, reaching 84.2 percent in 1909 . Owing to such excellent asset management, the family's income rose from 57,637 yen in 1892 to 529,998 yen in 1909. The number of stocks increased from 8 in 1892 to 24 in 1909 . The family invested not only in banks and railway companies but also in such industries as electric power, gas, textiles, and sugar. ${ }^{27}$

Thus, equity investment was the most important source of income of the daimyo in industrializing Japan. Some of them acted as kazoku, supported by aggressive equity trading. At the same time, their investment activities played a major role in the economic and business development of modern Japan, including local communities.

\section{Business and Social Activities of Daimyo: The Case of Tsugaru Tsuguakira Participation in Enterprises and Shareholding}

Here, we discuss the business and social activities of Tsugaru Tsuguakira (1840-1916), who ranks 17th in Table1. Throughout the Tokugawa period, the Tsugaru family governed Hirosaki han, currently known as Tsugaru region in Aomori prefecture, located in northeast part of Japan. This family had 47,000 koku after c.1600, 70,000 koku after 1805, and $100,000 \mathrm{koku}$ after $1808 .^{28}$ As most daimyo had only less than 50,000 koku, Hirosaki han was proud of its relatively large scale.

Tsuguakira was born in 1840 in Edo as the fourth son of Hosokawa Moriakira, the famous daimyo of Kumamoto han. Tsuguakira became son in law of the Tsugaru family in 1857, assumed the twelfth lord of this family, and became the last daimyo of Hirosaki han in 1859. In June 1869, Tsuguakira was appointed a governor at Hirosaki hanchiji by the Meiji government. After the abolishment of han in 1871, the government ordered the daimyo, including Tsuguakira, to resign from the hanchiji, and Tsuguakira moved to Tokyo along with the other peers, and lived there for 45 years from 1871 to 1916. During this period, he returned to his former domain only a few times. ${ }^{29}$ In July 1884 , he became a count. What did he do in Tokyo?

It is noteworthy that Tsugaru played important roles in two previously mentioned companies: The Fifteenth Bank and the Japan Railroad Company. He became a director 
of the bank, and the 11th-largest shareholder of the railroad company in $1896 .{ }^{30}$ In addition, Tsugaru invested in some other companies. Figure 1 shows their names and the locations of their headquarters during the period December 31, 1900 to January 1902. This figure indicates that Tsugaru intensively invested in railway companies and banks. In particular, it is notable that he had shares in Tsugaru Tetsudo Company, which operated in his former han, suggesting he retained a connection with people of the former domain in terms of money, even after moving to Tokyo.

[Figure 1 near here]

[Table 8 near here]

\section{Five Types of Financial Support: Strong Ties with Former Domain}

Table 8 presents a list of financial support provided by Tsugaru Tsuguakira in 1893-1916, which are written in his biography. We classify his financial support into five types, as follows. Type 1 is help to poor people and victims of natural disasters, bad harvests, or wars in Aomori prefecture, including his former domain. As this region was located in an area of Japan with a harsh natural environment. Tsugaru often provided such financial help. Type 2 is support to build and maintain facilities for the people of Aomori prefecture, for example, a park at Hirosaki Castle ruins, the base of the Tsugaru family. Type 3 is support to improve the educational environment of the people of Aomori prefecture. Tsugaru invested in human capital, as we soon explain in detail. Type 4 is other types of help for the people of Aomori prefecture. Type 5 is support unrelated to Aomori prefecture, including donations to the Ministry of the Imperial Household for construction costs at the Imperial palace, shrines, kado society for traditional Japanese poetry, and Hakuaisha, which later became the Red Cross Society of Japan. ${ }^{31}$

As for the financial support by Tsugaru, first, all types of support except for type 5 were given to the people of Aomori prefecture, which suggests there were social ties between Tsuguakira and his former han. Second, Jokun-kyoku, the Decoration Bureau, and so on awarded Tsuguakira medals for his contribution to help disaster victims and poor people. This implies that caring for socially vulnerable people was considered a socially expected role of kazoku at that time. Finally, Tsugaru made a great effort to support education. In particular, he made a significant contribution to the foundation and development of Toogijuku Junior High School in Hirosaki, a private junior high school that placed great importance on English learning. 


\section{Investment in Human Capital}

Nationalwide Trend

Among the daimyo, Tsuguakira was not the only one who made a special effort to support education. After Japan's opening to the world in the 1850s, its education policy changed in reaction to the institutional reform of local government. Most han put effort into training people in order to make them understand Western studies. Thus, some han established schools at which Western studies were taught, and sent people to study in developing areas, for example, in Tokyo and/or overseas countries. The number of such people reached the thousands before the abolishment of han. ${ }^{32}$ However, with the reform from han to prefectures, the talent-training system that had been supported by the han could not be maintained by the local government, and many schools of the former han were abolished.

In such a situation, some former feudal lords and ex-samurai started to support the local education system for young people, including the establishment of new schools and student scholarships. ${ }^{33}$ Thus, the daimyo became investors not only in modern industry but also in education and human capital.

\section{Financial Support for Young People of Aomori Prefecture}

Before the abolishment of han, like other han, Hirosaki han sent people outside of the han in order to learn mainly Western studies and built schools. The names of people who were dispatched from Hirosaki han to study from January 1861 to July 1871, and the purposes of their trips have been listed. ${ }^{34}$ Many people learned, in particular, military science, foreign languages, and other Western studies. The aims relating to Western studies gradually increased and several of the students from Aomori prefecture belonged to Keio Gijuku, a private school established by Fukuzawa Yukichi (1835-1901) in Tokyo in $1858 .{ }^{35}$ Fukuzawa set up a school for young Japanese men to learn Western studies, such as economics, the history of the US and UK, physics, and geography, using English textbooks. ${ }^{36}$ In the records of Hirosaki han in 1872, the purpose of this domestic study trip project was not only to learn Western studies, including military science, but also to build human networks. ${ }^{37}$ In addition, Hirosaki han established Eigakuryo, a school of English learning, and Kangakuryo, a school of Chinese classics for samurai in Hirosaki in 1871. Eigakuryo invited special teachers for English education, such as Nagashima Sadajiro and Yoshikawa Yasujiro, from Keio Gijuku and Shizuoka han.

As a consequence of the abolishment of han, this educational project was immediately stopped. However, Tsugaru continued with his dedicated efforts in human capital investment for the people of the former domain from the following two sides. One 
was the support for Toogijuku. Tsugaru provided not only funds for its establishment but also to build the schoolhouse. Furthermore, thereafter he often helped the school when it faced serious financial crises. ${ }^{38}$ The initial central members for the establishment and management of the school included the abovementioned Yoshikawa, as well as Kikuchi Kuro, an ex-samurai in Hirosaki han, who was close to Tsugaru. Prior to setting up this school, Kikuchi stayed in Tokyo to learn Western studies at Keio Gijuku and in Kagoshima to study military systems from 1869 to $1870 .{ }^{39}$ Kikuchi later stated that he decided to establish a modern school in Hirosaki when he stayed in Kagoshima han. In addition, Tsugaru financially supported Shuyosha, a scholarship foundation for students from the former territory to study in Tokyo, which was established in 1900 by the scholarship organization of Aomori prefecture. The foundation managed the dormitory, which had capacity for 50 students, and supplied them with living space, private study rooms, a library, an assembly hall, a reception room, and an office room. The foundation also had a backyard in which the students could exercise. ${ }^{40}$ The scholarship program was mainly managed by ex-samurai, including Kikuchi Kuro. In addition, Iida Tatsumi, one of the important people in the scholarship organization, was close to the Tsugaru family. Incidentally, Tsugaru Tsuguakira refused a request to become the president of an exhibition held by private agricultural and mercantile groups in Tsugaru region. ${ }^{41}$ After the abolishment of han in 1871, Tsugaru cared significantly about the improvement of educational environment for the people of Aomori prefecture, designed by his retainers.

\section{Background and Consequences of Tsugaru's Educational Investment}

The reasons Tsugaru invested in Toogijuku are said to be as follows: first, he recognized the importance of cultivating talented people, who were familiar with Western studies, and he tried to continue human capital development projects after the abolishment of han. ${ }^{42}$ In addition, Tsugaru and Nishidate Kosei, the former steward of the Tsugaru family, promised with Kikuchi to support the school, because Kikuchi had negotiated the government officials as an agent of the Tsugaru family to solve the family's financial problems. At the time, Kikuchi made full use of the human connections he had built during his domestic study trip. ${ }^{43}$

Toogijuku became an important place to connect between Japan and foreign countries in Japan's Westernizing Meiji period. Since the school's foundation, most of its curriculum, teaching method, and textbooks followed those of Keio Gijuku. ${ }^{44}$ In addition, Kikuchi strongly hoped that Toogijuku would become a school whose students could learn correct English pronunciation, conversation, and writing and thus, it became the first school in north-east Japan to invite native English teachers. ${ }^{45}$ In 1877 , five students 
were sent abroad to study at Asbury University in the US, with the support of John Ing, a foreign teacher of the school. According to the alumni association list, Toogijuku students came from not only cities and rural areas in Aomori prefecture but also other prefectures from around the country. There are 2649 names of male and female on the graduate list published in 1901, of which 175 are from other prefectures (Figure 2). ${ }^{46}$ Some of the school's graduates are listed in a document about the school's history published in 1908, and were active as government officials and local public servants (52 people, including 11 engineers, and 10 judges), educators (47 people, including 26 teachers of public junior high school, 6 lecturers and professors, 4 teachers of higher normal school, and 3 teachers of agricultural school), managers and employees of commerce and industries (36 people, including 5 directors and managers of banks, 5 of whom worked in the US $)^{47}$, military and navy (33), medical officials (33), newspaper reporters (24), politicians (22, including 16 local politicians and 6 national politicians), Christian officials (17), lawyers (15), navigators (12), primary industry workers (5) and priests (4). ${ }^{48}$ These people worked not only in Aomori prefecture but also throughout the country.

Tsugaru once stopped financial support to Toogijuku in 1892. It is said this was caused by the opposition of the ex-samurai of former domain. This could mean that Tsugaru could not sustain his power in the former territory as before. This remains as a future task to clarify.

[Figure 2 near here]

\section{Concluding Remarks: Daimyo Class in Economic History in the Meiji Era}

During the great change of Japanese society in the Meiji Restoration, while the ruling feudal class of samurai declined as a whole, their top members, daimyo, became richer than in the Tokugawa period, and some of them became among the wealthiest people in Japan.

Many daimyo, who were prominently wealthy people, became the most important sponsors of early Japanese modern companies in the 19th century after the 1880s. However, it is also noteworthy that in the newly established Japanese peerage, kazoku, including the daimyo, were deemed as the protectors of the royal family (koshitsu no hanpei ), and were obliged to restrain from speculative activities. Therefore, it was very difficult for the daimyo to develop as entrepreneurs. In fact, in the process of Japan's industrialization, especially in and after the First World War (1914-1918), their contribution toward supplying funds evidently decreased compared with emerging private entrepreneurs. 
Nevertheless, the daimyo were not only the supplier of industrial funds, but also the supporters to their ex-retainers, who hoped to become entrepreneurs, as a class of local men of high repute. Furthermore, the daimyo fostered local human capital through providing educational opportunities for young people. In summary, the daimyo indirectly helped Japan's industrialization. 
Table 1. Kazoku of former feudal lords in July 1869

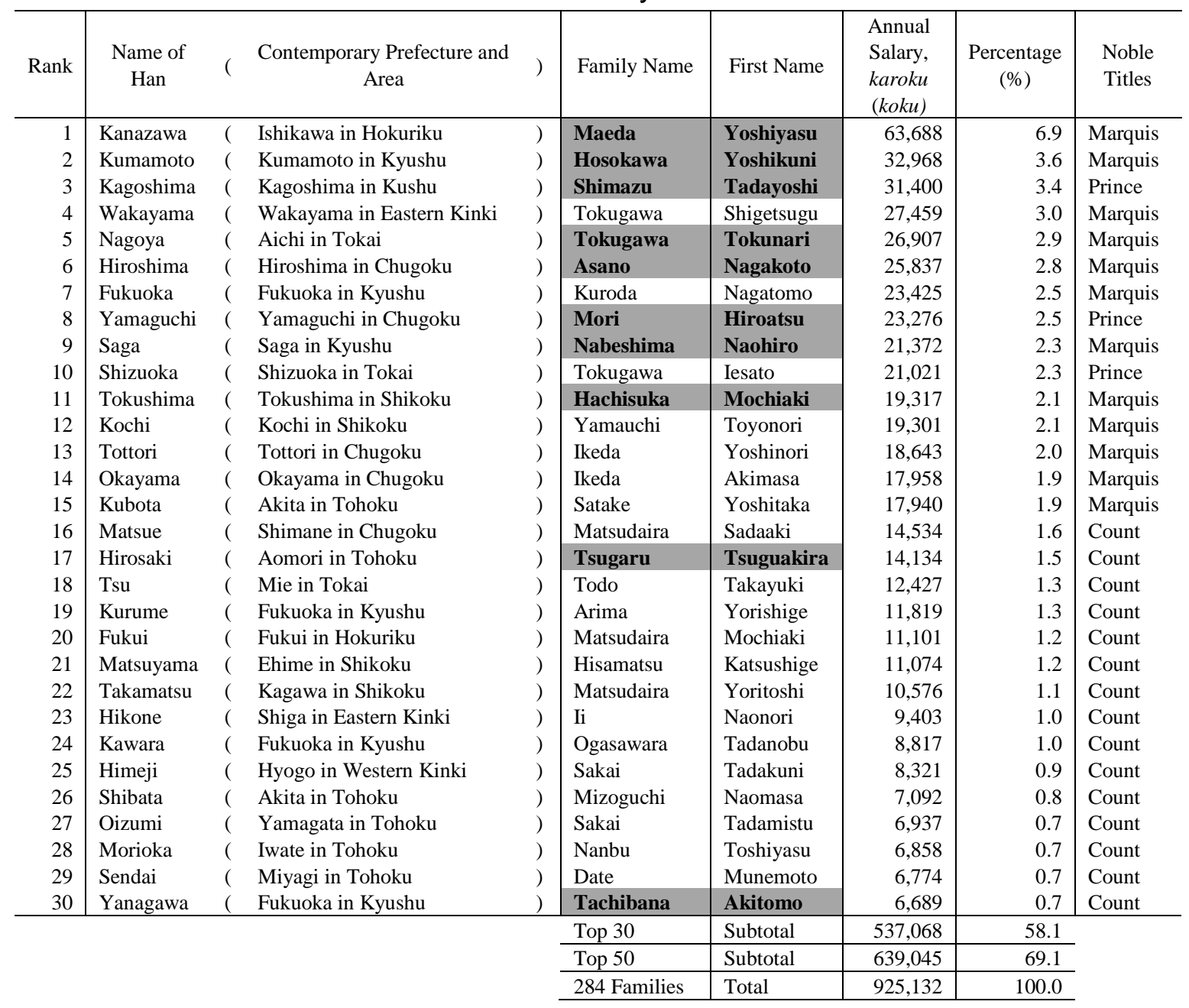

Source: Kasumi Kaikan Shoke Shiryo Chosa Iinkai, Kazoku Seido Shiryo-shu, 4-26.

Note: The boldface typed names are found in this paper. 
Table 2. Ranking of major shareholders in 1897

\begin{tabular}{|c|c|c|c|c|}
\hline Rank & Shareholder & Status & Number of shares & Number of issues \\
\hline 1 & The Fifteen Bank & Bank & 310,381 & 4 \\
\hline 2 & Kuranokami & Imperial court & 203,070 & 6 \\
\hline 3 & Iwasaki Hisaya & Businessman & 125,257 & 10 \\
\hline 4 & Mitsui Bank & Bank & 103,126 & 12 \\
\hline 5 & Yasuda Bank & Bank & 51,489 & \\
\hline 6 & Maeda Toshitsugu & Marquis & 43,127 & 9 \\
\hline 7 & Shibusawa Eiichi & Businessman & 28,780 & 16 \\
\hline 8 & Shimazu Tadayoshi & Prince & 27,371 & \\
\hline 9 & Asano Nagakoto & Marquis & 25,447 & 3 \\
\hline 10 & Goryokyoku & Imperial court & 23,492 & 2 \\
\hline 11 & Tokugawa Mochitsugu & Marquis & 20,424 & \\
\hline 12 & Hara Rokuro & Businessman & 19,304 & 12 \\
\hline 13 & Nabeshima Naohiro & Marquis & 19,232 & 6 \\
\hline 14 & Watanabe Jiemon & Businessman & 17,561 & 14 \\
\hline 15 & Hara Zenzaburo & Businessman & 17,221 & 9 \\
\hline 16 & Asano Soichiro & Businessman & 16,983 & 9 \\
\hline 17 & Mori Motoakira & Prince & 16,768 & 6 \\
\hline 18 & Amemiya Keijiro & Businessman & 15,214 & 6 \\
\hline 19 & Tokugawa Yoshiakira & Marquis & 15,024 & \\
\hline 20 & Nomoto Teijiro & Businessman & 14,802 & 5 \\
\hline 21 & Abe Hikotaro & Businessman & 13,245 & 7 \\
\hline 22 & Tanaka Heihachi & Businessman & 12,681 & 9 \\
\hline 23 & Hachisuka Mochiaki & Marquis & 12,660 & 6 \\
\hline 24 & Yamamoto Hidetoshi & Businessman & 11,160 & 1 \\
\hline 25 & Ichimura Soube & Businessman & 10,524 & 2 \\
\hline 26 & Mogi Bank & Bank & 9,575 & \\
\hline 27 & Hiranuma Senzo & Businessman & 9,440 & 8 \\
\hline 28 & Murakami Tasaburo & Businessman & 9,185 & 7 \\
\hline 29 & Yokohama Bank & Bank & 8,800 & 4 \\
\hline 30 & Japan Railway Company & Company & 8,653 & 1 \\
\hline 31 & Yasuda Zenjiro & Businessman & 8,608 & 8 \\
\hline 32 & Adachi Bank & Bank & 8,241 & 3 \\
\hline 33 & Watanabe Fukusaburo & Businessman & 8,158 & \\
\hline 34 & Hosokawa Morishige & Marquis & $\mathbf{7 , 8 7 2}$ & 2 \\
\hline 35 & Kato Tokuzo & Businessman & 7,480 & 10 \\
\hline 36 & Tanaka Bank & Bank & 7,221 & 1 \\
\hline 37 & Morimura Ichizaemon & Businessman & 7,172 & 6 \\
\hline 38 & Teikoku Marine Insurance Company & Insurance Company & 7,000 & 2 \\
\hline 39 & Iwata Sakube & Businessman & 6,502 & 4 \\
\hline 40 & Tanaka Shinshichi & Businessman & 6,373 & 3 \\
\hline 41 & Wakao Ikuzo & Businessman & 6,263 & 6 \\
\hline 42 & Amemiya Shinichiro & Businessman & 6,180 & 1 \\
\hline 43 & Date Munenobu & Marquis & 5,976 & 2 \\
\hline 44 & Nezu Kazuhide & Businessman & 5,812 & 1 \\
\hline 45 & Momiyama Hanzaburo & Businessman & 5,564 & 7 \\
\hline 46 & Ueba Katsue & Businessman & 5,460 & 1 \\
\hline 47 & Shimazu Tadanari & Prince & 5,443 & 3 \\
\hline 48 & Kawasaki Hachiemon & Businessman & 5,305 & 6 \\
\hline 49 & Osaka Savings Bank & Bank & 5,250 & 1 \\
\hline 50 & Saionji Kiminari & Businessman & 5,204 & 4 \\
\hline
\end{tabular}

\begin{tabular}{|c|c|c|c|c|}
\hline Rank & Shareholder & Status & Number of shares & Number of issues \\
\hline 51 & Ikegami Nakasaburo & Businessman & 5,051 & 5 \\
\hline 52 & Kitamura Eiichiro & Businessman & 5,014 & 5 \\
\hline 53 & Hibiya Heizaemon & Businessman & 5,012 & 5 \\
\hline 54 & Mogi Soube & Businessman & 5,003 & 6 \\
\hline 55 & Iwakura Tomosada & Prince & 5,000 & 1 \\
\hline 56 & Hisamatsu Sadakoto & Count & 5,000 & 1 \\
\hline 57 & Yamauchi Toyokage & Marquis & 4,828 & 2 \\
\hline 58 & Horikoshi Kakujiro & Businessman & 4,736 & 2 \\
\hline 59 & Wakao Ippei & Businessman & 4,721 & 3 \\
\hline 60 & Oyamada Shinzo & Businessman & 4,529 & 3 \\
\hline 61 & Kihara Chube & Businessman & 4,500 & 2 \\
\hline 62 & Baba Michihisa & Businessman & 4,365 & 3 \\
\hline 63 & Tajima Shinobu & Steward of Mori & 4,246 & 4 \\
\hline 64 & Ii Naonori & Count & 4,134 & 2 \\
\hline 65 & Tamura Hanjuro & Businessman & 4,078 & 4 \\
\hline 66 & Tokyo prefecture & Local government & 4,000 & 1 \\
\hline 67 & Ookawa Heizaburo & Businessman & 3,961 & 2 \\
\hline 68 & Fujita Gumi & Zaibatsu & 3,950 & 2 \\
\hline 69 & Ono Kinroku & Businessman & 3,881 & 9 \\
\hline 70 & Komuro Shinobu & Businessman & 3,800 & 3 \\
\hline 71 & Matsudaira Yoritoshi & Count & 3,754 & 2 \\
\hline 72 & Yamawaki Zensuke & Businessman & 3,750 & 1 \\
\hline 73 & Hayakawa Kaneaki & Steward of Shimazu & 3,700 & 1 \\
\hline 74 & Minoda Chozaburo & Businessman & 3,479 & 3 \\
\hline 75 & Hiratsuka Kihe & Businessman & 3,413 & 1 \\
\hline 76 & Ishizaki Seizo & Businessman & 3,383 & 5 \\
\hline 77 & Meiji Fire Insurance Company & Insurance Company & 3,336 & 1 \\
\hline 78 & Ino Kumekichi & Businessman & 3,327 & 4 \\
\hline 79 & Sumitomo Kichizaemon & Businessman & 3,277 & 2 \\
\hline 80 & Takeda Chusaku & Businessman & 3,160 & 2 \\
\hline 81 & Nanjo Shinrokuro & Businessman & 3,118 & 4 \\
\hline 82 & Watanabe Hiromoto & Businessman & 3,100 & 4 \\
\hline 83 & Ootani Kahe & Businessman & 3,039 & 6 \\
\hline 84 & Ikeda Akimasa & Marquis & 3,000 & 1 \\
\hline 85 & Souma Aritane & Viscount & 3,000 & 1 \\
\hline 86 & Tsugaru Tsuguakira & Count & 3,000 & 1 \\
\hline 87 & Tokugawa Iesato & Prince & 3,000 & 1 \\
\hline 88 & Matsura Akira & Count & 3,000 & 1 \\
\hline 89 & Yamazaki Ryutoku & Businessman & 3,000 & 1 \\
\hline 90 & Watanabe Ryukichi & Businessman & 3,000 & 1 \\
\hline 91 & Tanaka Nagamasa & Steward of Nabeshima & 2,968 & 2 \\
\hline 92 & Kikkawa Tsunetake & Viscount & 2,936 & 2 \\
\hline 93 & Kawada Ryokichi & Businessman & 2,904 & 2 \\
\hline 94 & Satsuma Jihe & Businessman & 2,900 & 3 \\
\hline 95 & Tokuda Kohe & Businessman & 2,865 & 2 \\
\hline 96 & Matsui Zenhachi & Businessman & 2,865 & 1 \\
\hline 97 & Inai Nagatoshi & Steward of Hachisuka & 2,836 & 4 \\
\hline & Masuda Takashi & Businessman & 2,761 & 8 \\
\hline 99 & Kimura Riemon & Businessman & 2,708 & 4 \\
\hline & Hiranuma Kyusaburo & & & \\
\hline
\end{tabular}

Source: Sawai, "Shiryo: Meiji-ki no Okabunushi," 256-258.

Note: Number total firms 331, number of total shareholders 1,956, and number of total shares 2,224,115. 
Table 3. Ranking of major shareholders in 1907

\begin{tabular}{|c|c|c|c|c|}
\hline Rank & Shareholder & Status & Number of shares & Number of issues \\
\hline 1 & Ministry of Finance & Government & 520,000 & 2 \\
\hline 2 & Kuranokami & Imperial court & 232,384 & 8 \\
\hline 3 & Mitsui Bank & Bank & 107,489 & 4 \\
\hline 4 & Osaka Steamship Company & Company & 75,430 & 1 \\
\hline 5 & Okura Kihachiro & Businessman & 74,034 & 13 \\
\hline 6 & NYK Line Japan & Company & 70,189 & 1 \\
\hline 7 & Suzuki Tozaburo & Businessman & 65,093 & 2 \\
\hline 8 & Watanabe Jiemon & Businessman & 57,149 & 8 \\
\hline 9 & Asano Soichiro & Businessman & 51,291 & 9 \\
\hline 10 & Mitsui Family & Zaibatsu & 50,158 & 1 \\
\hline 11 & Amemiya Keijiro & Businessman & 48,469 & 7 \\
\hline 12 & Wakao Ippei & Businessman & 48,249 & 2 \\
\hline 13 & Yamaguchi Tatsutaro & Businessman & 43,880 & 6 \\
\hline 14 & Shibusawa Eiichi & Businessman & 36,930 & 19 \\
\hline 15 & Iwasaki Hisaya & Businessman & $\begin{array}{l}30,997 \\
30,907\end{array}$ & 6 \\
\hline 16 & Yasuda Zenjiro & Businessman & 30,802 & 12 \\
\hline 17 & Murai Kichibe & Businessman & 30,140 & 6 \\
\hline 18 & Teikoku Life Insurance Company & Insurance Company & 29,848 & \\
\hline 19 & Wakao Tamizo & Businessman & 28,894 & \\
\hline 20 & Kuryu Buemon & Businessman & 24,988 & 4 \\
\hline 21 & Hibiya Heizaemon & Businessman & 24,841 & 3 \\
\hline 22 & Wakao Bank & Bank & 23,571 & 4 \\
\hline 23 & Nezu Kaichiro & Businessman & 22,322 & 6 \\
\hline 24 & Ueda Rokurobe & Businessman & 20,000 & 1 \\
\hline 25 & Maeda Toshinari & Marquis & 19,915 & 3 \\
\hline 26 & Watanabe Fukusaburo & Businessman & 19,467 & \\
\hline 27 & Ohashi Shintaro & Businessman & 19,181 & \\
\hline 28 & Family Company of Mitsubishi & Zaibatsu & 19,100 & 2 \\
\hline 29 & Hoden Oil Company & Company & 19,000 & 1 \\
\hline 30 & Baba Michihisa & Businessman & 18,620 & 9 \\
\hline 31 & Ono Kinroku & Businessman & 18,237 & 4 \\
\hline 32 & Hara Rokuro & Businessman & 18,031 & 6 \\
\hline 33 & Teikoku Maritime Transport Fire Insurance Company & Insurance Company & 18,000 & 4 \\
\hline 34 & Nishiwaki Saisaburo & Businessman & 17,664 & 4 \\
\hline 35 & General Electric Company & Company & 16,170 & \\
\hline 36 & Abe Yukibe & Businessman & 15,834 & 2 \\
\hline 37 & Mogi Bank & Bank & 15,651 & 5 \\
\hline 38 & Yasuda Zenzaburo & Businessman & 15,600 & 5 \\
\hline 39 & Date Munenobu & Marquis & 15,499 & 4 \\
\hline 40 & Suzuki Keizo & Businessman & 15,352 & 3 \\
\hline 41 & Tajima Shinobu & Steward of Mori & 15,313 & 4 \\
\hline 42 & Yasuda Bank & Bank & 15,265 & 3 \\
\hline 43 & Niigata prefecture & Local government & 15,000 & 1 \\
\hline 44 & Shizuoka prefecture & Local government & 15,000 & 1 \\
\hline 45 & Nagano prefecture & Local government & 15,000 & 1 \\
\hline 46 & Go Seinosuke & Businessman & 14,580 & 2 \\
\hline 47 & Oda Sataro & Businessman & 13,909 & 1 \\
\hline 48 & Satake Sakutaro & Businessman & 13,800 & 2 \\
\hline 49 & Minomura Yasutaro & Businessman & 13,117 & 5 \\
\hline 50 & Matsudaira Yorinaga & Count & 12,985 & 2 \\
\hline
\end{tabular}

\begin{tabular}{|c|c|c|c|c|}
\hline Rank & Shareholder & Status & Number of shares & Number of issues \\
\hline 51 & Toshimitsu Tsurumatsu & Businessman & 12,813 & 1 \\
\hline 52 & Wakao Ikuzo & Businessman & 12,745 & 5 \\
\hline 53 & Tokugawa Yoshiakira & Marquis & 12,575 & \\
\hline 54 & Hara Zenichiro & Businessman & 12,567 & \\
\hline 55 & Morimura Ichizaemon & Businessman & 12,218 & 3 \\
\hline 56 & Sugimura Jinbe & Businessman & 12,000 & 1 \\
\hline 57 & Shimazu Tadashige & Prince & 11,624 & \\
\hline 58 & Chiba prefecture & Local government & 11,480 & 1 \\
\hline 59 & Masuda Masuzo & Businessman & 11,250 & 1 \\
\hline 60 & Phimerus Mining Company & Company & 11,000 & \\
\hline 61 & Friedrich Adolphkoenig & Businessman & 11,000 & \\
\hline 62 & Furukawa Toranosuke & Businessman & 10,500 & 2 \\
\hline 63 & Uchino Goroza & Businessman & 10,500 & 3 \\
\hline 64 & Horikoshi Kakujiro & Businessman & 10,248 & \\
\hline 65 & Tanaka Store & Company & 10,022 & 1 \\
\hline 66 & Ibaraki prefecture & Local government & 10,000 & 1 \\
\hline 67 & Fujita Kotaro & Businessman & 10,000 & 1 \\
\hline 68 & Tokyo Fire Maritime Transport Insurance Company & Insurance Company & 9,800 & \\
\hline 69 & The Fifteen Bank & Bank & 9,600 & 2 \\
\hline 70 & Kamiya Denbe & Businessman & 9,511 & 2 \\
\hline 71 & Ito Denshichi & Businessman & 9,178 & 1 \\
\hline 72 & Maekawa Tahe & Businessman & 9,000 & \\
\hline 73 & Aichi prefecture & Local government & 8,770 & 1 \\
\hline 74 & Yokohama Fire Maritime Insurance Company & Insurance Company & 8,740 & 2 \\
\hline 75 & Baku Shoho & Businessman & 8,660 & \\
\hline 76 & Nakazawa Hikokichi & Businessman & 8,552 & \\
\hline 77 & Matsumoto Tatsuo & Businessman & 8,466 & 1 \\
\hline 78 & Fujimoto Seibe & Businessman & 8,326 & 3 \\
\hline 79 & Yamazaki Unosuke & Businessman & 8,150 & \\
\hline 80 & Tanaka Shinshichi & Businessman & 8,082 & 2 \\
\hline 81 & Mitsui Yonosuke & Businessman & 8,000 & \\
\hline 82 & Asano Nagakoto & Marquis & 8,000 & 2 \\
\hline 83 & Gunma prefecture & Local government & 7,954 & \\
\hline 84 & Fukushima Namizo & Businessman & 7,829 & 3 \\
\hline 85 & Nabeshima Naohiro & Marquis & 7,771 & 3 \\
\hline 86 & Asada Matashichi & Businessman & 7,757 & \\
\hline 87 & Yamagata Yuzaburo & Businessman & 7,621 & 4 \\
\hline 88 & Saga Shotaro & Businessman & 7,500 & 2 \\
\hline 89 & Fukukawa Chuhe & Businessman & 7,496 & 1 \\
\hline 90 & Minoda Chozaburo & Businessman & 7,411 & 3 \\
\hline 91 & Honda Hiroshi & Businessman & 7,406 & 4 \\
\hline 92 & Shiba Yoshikane & Businessman & 7,300 & 1 \\
\hline 93 & Ono Seikei & Businessman & 7,255 & 6 \\
\hline 94 & Ono Tokusaburo & Businessman & 7,164 & 2 \\
\hline 95 & Tomikura Rinzo & Businessman & 7,135 & 1 \\
\hline 96 & Masuda Takashi & Businessman & 7,106 & 5 \\
\hline 97 & Shirai Enpei & Businessman & 7,104 & 3 \\
\hline 98 & Otani Kahei & Businessman & 7,038 & 5 \\
\hline 99 & Kawasaki Bank & Bank & 7,001 & 3 \\
\hline 100 & Yamamoto Tatsuo & Politician & 7,000 & 1 \\
\hline
\end{tabular}

Source: Sawai, "Shiryo: Meiji-ki no Okabunushi," 256-258.

Note: Number total firms 1,374, number of total shareholders 4,051, and number of total shares 4,839,065. 
Table 4. Noblemen's Holding Structure (more than 5,000 shares owned, 1897)

\begin{tabular}{|c|c|c|c|c|c|c|c|c|c|c|c|c|c|c|}
\hline \multirow[b]{2}{*}{ Rank } & \multirow[b]{2}{*}{ Name } & \multirow[b]{2}{*}{ Status } & \multirow[b]{2}{*}{$\begin{array}{l}\# \text { of } \\
\text { shares }\end{array}$} & \multirow[b]{2}{*}{$\begin{array}{l}\# \text { of } \\
\text { issues }\end{array}$} & \multicolumn{10}{|c|}{ Composition of the issues } \\
\hline & & & & & Firm & $\begin{array}{l}\text { \# of } \\
\text { shares }\end{array}$ & Firm & $\begin{array}{l}\text { \# of } \\
\text { shares }\end{array}$ & Firm & $\begin{array}{c}\text { \# of } \\
\text { shares }\end{array}$ & Firm & $\begin{array}{l}\text { \# of } \\
\text { shares }\end{array}$ & Firm & $\begin{array}{l}\text { \# of } \\
\text { shares }\end{array}$ \\
\hline \multirow{2}{*}{6} & \multirow{2}{*}{$\begin{array}{l}\text { Maeda } \\
\text { Toshitsugu }\end{array}$} & \multirow{2}{*}{ Marquis } & \multirow{2}{*}{43,127} & \multirow{2}{*}{9} & $\begin{array}{l}\text { Japan Railway } \\
\text { Company }\end{array}$ & 17,978 & $\begin{array}{l}\text { Meiji Commercial } \\
\text { Bank }\end{array}$ & 10,000 & $\begin{array}{l}\text { The 15th } \\
\text { Bank }\end{array}$ & 5,000 & $\begin{array}{l}\text { Tokio Marine } \\
\text { Insurance }\end{array}$ & 3,584 & NYK Line Japan & 2,065 \\
\hline & & & & & Nanao Bank & 2,000 & Ganetsu Railway & 1,000 & Bank of Japan & 1,000 & $\begin{array}{l}\text { Kinjo Saving } \\
\text { Bank }\end{array}$ & 500 & & \\
\hline 8 & $\begin{array}{c}\text { Shimazu } \\
\text { Tadayoshi }\end{array}$ & Prince & 27,371 & 3 & $\begin{array}{l}\text { Japan Railway } \\
\text { Company }\end{array}$ & 13,947 & The 15th Bank & 8,000 & The 5th Bank & 5,424 & & & & \\
\hline 9 & $\begin{array}{c}\text { Asano } \\
\text { Nagakoto }\end{array}$ & Marquis & 25,447 & 3 & $\begin{array}{l}\text { Japan Railway } \\
\text { Company }\end{array}$ & 17,947 & The 15th Bank & 4,500 & Teiyu Bank & 3,000 & & & & \\
\hline 11 & $\begin{array}{c}\text { Tokugawa } \\
\text { Mochitugu }\end{array}$ & Marquis & 20,424 & 2 & $\begin{array}{l}\text { Japan Railway } \\
\text { Company }\end{array}$ & 15,424 & The 15th Bank & 5,000 & & & & & & \\
\hline \multirow[t]{2}{*}{13} & \multirow{2}{*}{$\begin{array}{l}\text { Nabeshima } \\
\text { Naohiro }\end{array}$} & \multirow[t]{2}{*}{ Marquis } & \multirow[t]{2}{*}{19,232} & \multirow[t]{2}{*}{6} & $\begin{array}{l}\text { Japan Railway } \\
\text { Company }\end{array}$ & 10,230 & NYK Line Japan & 2,500 & $\begin{array}{l}\text { The 30th } \\
\text { Bank }\end{array}$ & 2,000 & The 1st Bank & 2,000 & Bank of Japan & 1,500 \\
\hline & & & & & The 2th Bank & 1,002 & & & & & & & & \\
\hline \multirow[t]{2}{*}{17} & \multirow{2}{*}{$\begin{array}{c}\text { Mori } \\
\text { Motoakira }\end{array}$} & \multirow[t]{2}{*}{ Prince } & \multirow[t]{2}{*}{16,768} & \multirow[t]{2}{*}{6} & The 15th Bank & 4,951 & $\begin{array}{l}\text { Hokkaido Coal } \\
\text { Train Company }\end{array}$ & 4,500 & $\begin{array}{l}\text { Tokio Marine } \\
\text { Insurance }\end{array}$ & 3,600 & $\begin{array}{l}\text { Sobu Railway } \\
\text { Company }\end{array}$ & 1,500 & $\begin{array}{l}\text { The Yokohama } \\
\text { Specie Bank }\end{array}$ & 1,400 \\
\hline & & & & & Kuratani Mining & 817 & & & & & & & & \\
\hline 19 & $\begin{array}{l}\text { Tokugawa } \\
\text { Yoshiakira } \\
\end{array}$ & Marquis & 15,024 & 2 & $\begin{array}{l}\text { Japan Railway } \\
\text { Company }\end{array}$ & 10,626 & The 15th Bank & 4,398 & & & & & & \\
\hline \multirow[t]{2}{*}{23} & \multirow[t]{2}{*}{$\begin{array}{l}\text { Hachisuka } \\
\text { Mochiaki }\end{array}$} & \multirow[t]{2}{*}{ Marquis } & \multirow[t]{2}{*}{12,660} & \multirow[t]{2}{*}{6} & $\begin{array}{l}\text { Tokio Marine } \\
\text { Insurance }\end{array}$ & 5,500 & The 89th Bank & 5,121 & $\begin{array}{l}\text { Japan } \\
\text { Refractories } \\
\text { Company }\end{array}$ & 845 & $\begin{array}{l}\text { Tokyo Electric } \\
\text { Power Company }\end{array}$ & 604 & $\begin{array}{l}\text { Tokyo Chemical } \\
\text { Fertilizer } \\
\text { Company }\end{array}$ & 400 \\
\hline & & & & & Tokyo Hat Company & 190 & & & & & & & & \\
\hline 34 & $\begin{array}{l}\text { Hosokawa } \\
\text { Morishige }\end{array}$ & Marquis & 7,872 & 2 & The 15th Bank & 4,572 & Higo Bank & 3,300 & & & & & & \\
\hline 43 & $\begin{array}{c}\text { Date } \\
\text { Munenobu }\end{array}$ & Marquis & 5,976 & 2 & The 20th Bank & 4,532 & $\begin{array}{l}\text { Kobu Railway } \\
\text { Company }\end{array}$ & 1,444 & & & & & & \\
\hline 47 & $\begin{array}{l}\text { Shimazu } \\
\text { Tadanari }\end{array}$ & Prince & 5,443 & 3 & The 5th Bank & 4,172 & Bank of Japan & 1,050 & $\begin{array}{l}\text { The 147th } \\
\text { Bank }\end{array}$ & 221 & & & & \\
\hline 55 & $\begin{array}{c}\text { Iwakura } \\
\text { Tomosada } \\
\end{array}$ & Prince & 5,000 & 1 & The 15th Bank & 5,000 & & & & & & & & \\
\hline 56 & $\begin{array}{c}\text { Hisamatsu } \\
\text { Sadakoto }\end{array}$ & Count & 5,000 & 1 & $\begin{array}{l}\text { Kobu Railway } \\
\text { Company }\end{array}$ & 5,000 & & & & & & & & \\
\hline
\end{tabular}

Source: Sawai, "Shiryo: Meiji-ki no Okabunushi,” 260. 
Table 5. Noblemen's Holding Structure (more than 10,000 shares owned, 1907)

\begin{tabular}{|c|c|c|c|c|c|c|c|c|c|c|c|c|}
\hline \multirow[b]{2}{*}{ Rank } & \multirow[b]{2}{*}{ Name } & \multirow[b]{2}{*}{ Status } & \multirow{2}{*}{$\begin{array}{l}\text { \# of } \\
\text { shares }\end{array}$} & \multirow{2}{*}{$\begin{array}{l}\text { \# of } \\
\text { issues }\end{array}$} & \multicolumn{8}{|c|}{ Composition of the issues } \\
\hline & & & & & Firm & $\begin{array}{l}\text { \# of } \\
\text { shares }\end{array}$ & Firm & $\begin{array}{l}\text { \# of } \\
\text { shares }\end{array}$ & Firm & $\begin{array}{l}\text { \# of } \\
\text { shares }\end{array}$ & Firm & $\begin{array}{l}\text { \# of } \\
\text { shares }\end{array}$ \\
\hline 25 & $\begin{array}{l}\text { Maeda } \\
\text { Toshinari }\end{array}$ & Marquis & 19,915 & 3 & $\begin{array}{l}\text { Meiji Commercial } \\
\text { Bank }\end{array}$ & 9,000 & The 15th Bank & 5,700 & NYK Line Japan & 5,215 & & \\
\hline 39 & $\begin{array}{l}\text { Date } \\
\text { Munenobu }\end{array}$ & Marquis & 15,499 & 4 & The 20th Bank & 9,319 & The 1st Bank & 4,376 & $\begin{array}{l}\text { Tokyo Ishikawajima } \\
\text { Shipbuilding Company }\end{array}$ & 944 & $\begin{array}{l}\text { Iwaki } \\
\text { Minning }\end{array}$ & 860 \\
\hline 50 & $\begin{array}{l}\text { Matsudaira } \\
\text { Yorinaga }\end{array}$ & Count & 12,985 & 2 & $\begin{array}{l}\text { Tokyo Railway } \\
\text { Company }\end{array}$ & 11,773 & $\begin{array}{l}\text { Odawara Electric } \\
\text { Railway Company }\end{array}$ & 1,212 & & & & \\
\hline 53 & $\begin{array}{l}\text { Tokugawa } \\
\text { Yoshiakira }\end{array}$ & Marquis & 12,575 & 4 & Aichi Bank & 6,714 & The 15th Bank & 3,527 & Hokkai Bank & 2,034 & $\begin{array}{l}\text { Maruhachi } \\
\text { Saving Bank }\end{array}$ & 300 \\
\hline 57 & $\begin{array}{l}\text { Shimazu } \\
\text { Tadashige }\end{array}$ & Prince & 11,624 & 2 & The 15th Bank & 6,000 & Naniwa Bank & 5,624 & & & & \\
\hline
\end{tabular}

Source: Sawai, "Shiryo: Meiji-ki no Okabunushi," 267.

Table 6. Revenue Structure of the Shimazu Family

\begin{tabular}{c|r|r|r|r|c}
\hline \multirow{2}{*}{ Year } & \multicolumn{4}{|c|}{ Composition (\%) } & \multirow{2}{*}{$\begin{array}{l}\text { Total } \\
\text { (yen) }\end{array}$} \\
\cline { 2 - 5 } & \multicolumn{1}{|c|}{ Bond } & Equity & \multicolumn{1}{c|}{ Business } & Others & \multicolumn{1}{c}{ (y) } \\
\hline 1885 & 1.3 & 93.1 & - & 5.6 & 107,740 \\
1892 & 5.2 & 73.4 & 20.0 & 1.5 & 178,173 \\
\hline
\end{tabular}

Source: Terao, "Daimyo Kazoku Shihon no Tanjo," 43. 
Table 7. Revenue Structure of the Kikkawa Family

\begin{tabular}{|c|c|c|c|c|c|c|c|c|}
\hline \multirow{3}{*}{ Year } & \multicolumn{7}{|c|}{ Composition $(\%)$} & \multirow{3}{*}{$\begin{array}{l}\text { Total } \\
\text { (yen) }\end{array}$} \\
\hline & \multirow[b]{2}{*}{ Bond } & \multicolumn{2}{|c|}{ Share } & \multirow{2}{*}{$\begin{array}{c}\text { Land } \\
\text { rent }\end{array}$} & \multirow{2}{*}{$\begin{array}{c}\text { Loan } \\
\text { interest }\end{array}$} & \multirow[b]{2}{*}{$\begin{array}{l}\text { Deposit } \\
\text { interest }\end{array}$} & \multirow[b]{2}{*}{ Others } & \\
\hline & & $\begin{array}{c}\text { Proportion } \\
(\%)\end{array}$ & $\begin{array}{c}\text { \# of } \\
\text { issues }\end{array}$ & & & & & \\
\hline 1892 & 26.3 & 22.2 & 8 & 25.9 & 9.3 & 15.4 & 0.8 & 57,631 \\
\hline 1893 & 26.7 & 22.8 & 10 & 26.6 & 7.1 & 14.8 & 2.0 & 63,115 \\
\hline 1894 & 25.7 & 26.4 & 10 & 27.8 & 8.6 & 8.9 & 2.5 & 66,190 \\
\hline 1895 & 26.9 & 34.1 & 12 & 24.8 & 7.4 & 4.8 & 2.3 & 73,657 \\
\hline 1896 & 26.2 & 36.9 & 15 & 24.8 & 6.3 & 4.2 & 1.6 & 71,337 \\
\hline 1897 & 12.6 & 63.1 & 16 & 17.4 & 3.1 & 2.3 & 1.6 & 125,066 \\
\hline 1898 & 16.3 & 47.6 & 18 & 25.2 & 4.2 & 4.1 & 2.6 & 88,842 \\
\hline 1899 & 11.7 & 51.1 & 18 & 29.6 & 3.8 & 1.2 & 2.7 & 101,689 \\
\hline 1900 & 7.5 & 48.4 & 18 & 39.3 & 2.1 & 1.1 & 1.6 & 146,559 \\
\hline 1901 & 9.8 & 57.5 & 19 & 26.7 & 1.8 & 0.8 & 3.4 & 108,112 \\
\hline 1902 & 11.2 & 52.1 & 19 & 31.8 & 1.7 & 0.6 & 2.6 & 88,626 \\
\hline 1903 & 8.0 & 59.2 & 21 & 27.5 & 1.0 & 1.6 & 2.7 & 116,999 \\
\hline 1904 & 6.3 & 59.6 & 22 & 31.0 & 0.8 & 0.8 & 1.6 & 127,695 \\
\hline 1905 & 7.1 & 61.8 & 21 & 26.8 & 0.8 & 0.7 & 2.8 & 135,671 \\
\hline 1906 & 8.8 & 64.2 & 21 & 24.5 & 0.5 & 0.9 & 1.0 & 186,560 \\
\hline 1907 & 4.8 & 73.3 & 26 & 19.1 & 0.5 & 1.4 & 0.9 & 262,263 \\
\hline 1908 & 5.9 & 65.4 & 30 & 26.3 & 0.6 & 0.9 & 0.7 & 188,114 \\
\hline 1909 & 5.7 & 84.2 & 24 & 8.6 & 0.4 & 0.6 & 0.5 & 529,998 \\
\hline
\end{tabular}

Source: Miura, "Meiji-ki ni okeru Kazoku Shihon no Keisei to Kougyoka Toshi," 5, 14-15. 
Table 8. Financial support by Tsugaru Tsuguakira: 1873-1916

\begin{tabular}{|c|c|c|c|c|c|c|c|}
\hline \multirow[t]{2}{*}{ Year } & \multirow[t]{2}{*}{ Helps to } & \multirow{2}{*}{$\begin{array}{l}\text { Amount } \\
\text { (Yen) }\end{array}$} & \multicolumn{4}{|c|}{$\begin{array}{c}\text { For people of the former domain } \\
\text { and Aomori prefecture }\end{array}$} & \multirow{2}{*}{$\begin{array}{l}\text { Other } \\
\text { Type5 } \\
\end{array}$} \\
\hline & & & Type1 & Type2 & Type3 & Type4 & \\
\hline 1871 & $\begin{array}{l}\text { Ex-samurai, doctors, painters, komono, } \\
\text { and craftspeople of the former domain }\end{array}$ & $\mathrm{n} / \mathrm{a}$ & $\checkmark$ & & & & \\
\hline \multirow[t]{2}{*}{1873} & $\begin{array}{l}\text { Construction cost of the Imperial Palace } \\
\text { for The Ministry of the Imperial } \\
\text { Household * }\end{array}$ & 1,000 & & & & & $\checkmark$ \\
\hline & $\begin{array}{l}\text { Funds to establish Toogijuku Junior } \\
\text { High School }\end{array}$ & 5,000 & & & $\checkmark$ & & \\
\hline $1874-1875$ & $\begin{array}{l}\text { Assembly hall for people of the former } \\
\text { domain in Tokyo }\end{array}$ & $\mathrm{n} / \mathrm{a}$ & & $\checkmark$ & & & \\
\hline $1875-1882$ & $\begin{array}{l}\text { Operating expenses for Toogijuku Junior } \\
\text { High School }\end{array}$ & 24,000 & & & $\checkmark$ & & \\
\hline 1877 & $\begin{array}{l}\text { Policemen in Tokyo who came from } \\
\text { Aomori prefecture }\end{array}$ & 450 & & & & $\checkmark$ & \\
\hline 1877 & $\begin{array}{l}\text { People of the former domain who } \\
\text { worshipped the Tsugaru ancestors }\end{array}$ & 300 & & & & $\checkmark$ & \\
\hline 1877 & People injured during the Seinan War** & 500 & \multicolumn{5}{|c|}{$\mathrm{n} / \mathrm{a}$} \\
\hline 1880 & Victims of fire in Hirosaki city** & 2,000 & $\checkmark$ & & & & \\
\hline 1882 & $\begin{array}{l}\text { Preservation society of Danzan Shrine in } \\
\text { Nara prefecture }\end{array}$ & 500 & & & & & $\checkmark$ \\
\hline 1883 & Toogijuku Junior High School & 10,000 & & & $\sqrt{ }$ & & \\
\hline 1885 & Kado Society & 200 & & & & & $\checkmark$ \\
\hline 1886 & Hakuaisha & 90 & & & & & $\checkmark$ \\
\hline 1890 & $\begin{array}{l}\text { Victims of poor crop in Tsugaru } \\
\text { region*** }\end{array}$ & 150 & $\checkmark$ & & & & \\
\hline $1893-1897$ & Toogijuku Junior High School & 1,500 & & & $\checkmark$ & & \\
\hline 1894 & $\begin{array}{l}\text { Hirosaki park, site of the Hirosaki Castle } \\
\text { ruins }\end{array}$ & $\mathrm{n} / \mathrm{a}$ & & $\checkmark$ & & & \\
\hline 1895 & $\begin{array}{l}\text { Poor military families of the former } \\
\text { domain }\end{array}$ & 544 & $\checkmark$ & & & & \\
\hline 1895 & $\begin{array}{l}\text { Dead soldiers from the former domain in } \\
\text { the Sino - Japanese War }\end{array}$ & n.a. & $\checkmark$ & & & & \\
\hline $1895-1899$ & $\begin{array}{l}\text { Military training institution established } \\
\text { by Aomori prefecture }\end{array}$ & 500 & & & $\checkmark$ & & \\
\hline 1896 & $\begin{array}{l}\text { Toogijuku Junior High School for land- } \\
\text { clearing work }\end{array}$ & $\mathrm{n} / \mathrm{a}$ & & & $\checkmark$ & & \\
\hline 1899 & $\begin{array}{l}\text { Students of Aomori prefecture's } \\
\text { dormitory in Tokyo }\end{array}$ & 1,000 & & & $\checkmark$ & & \\
\hline 1900 & $\begin{array}{l}\text { Poor people in Hirosaki and Aomori city } \\
\text { and Tsugaru region (presents given in } \\
\text { return for funeral offerings)*** }\end{array}$ & 425 & $\checkmark$ & & & & \\
\hline 1902 & $\begin{array}{l}\text { Victims of poor crop in Aomori } \\
\text { prefecture**** }\end{array}$ & 500 & $\checkmark$ & & & & \\
\hline 1909 & $\begin{array}{l}\text { Hirosaki park, site of the Hirosaki Castle } \\
\text { ruins }\end{array}$ & 1,000 & & $\checkmark$ & & & \\
\hline 1910 & Victims of fire in Aomori city $* * * *$ & 2,000 & $\checkmark$ & & & & \\
\hline
\end{tabular}

Source: Tsugaru Tsuguakira Ko Den Kanko-kai, Tsugaru Tsuguakira Ko Den.

Note: See the text for an explanation of the five types. Each asterisks denotes that the medal was awarded for Tsuguakira's contribution, * by The Ministry of the Imperial Household; ** by Dajokan, the supreme office of the Meiji government; *** by Jokun-kyoku, the Decoration Bureau. For the asterisk ****, no data is available. 


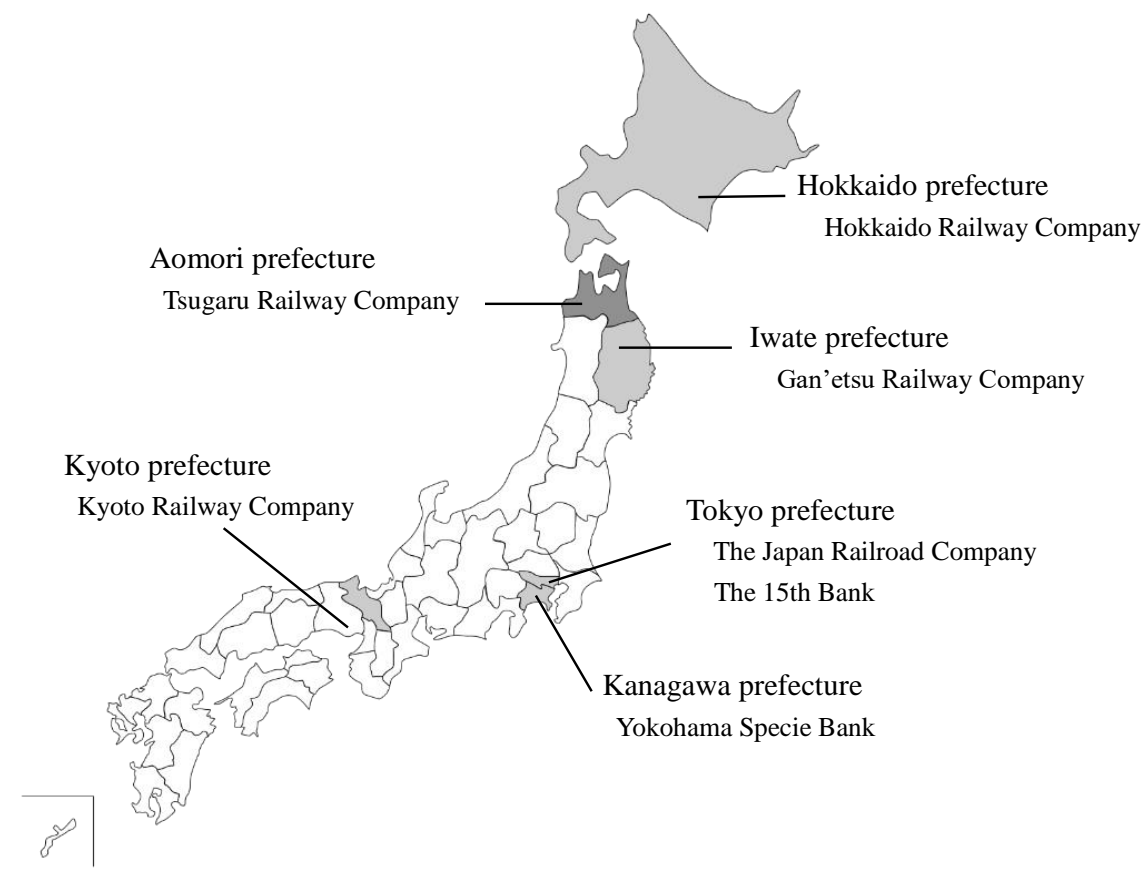

Figure 1. Enterprises in which Tsuguakira Tsugaru owned shares and the locations of their head offices during 31 December 1900 to January 1902

Source: Jugo Ginko Sonohoka Dome, 1901.

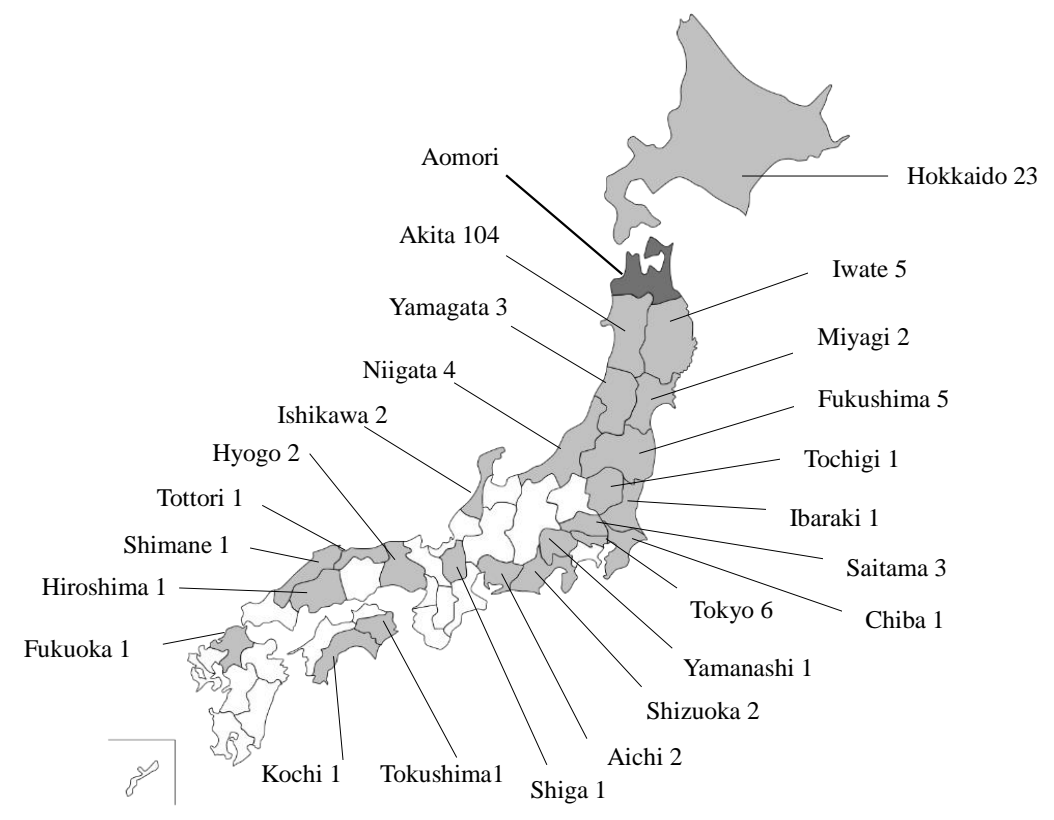

Figure 2. Graduates of Toogijuku by birthplace listed in the 1901 Alumni Directory (number of people)

Source: Toogijuku, Meiji Sanju-yo nen Gun-shi Betsu Dousou Meibo, 1901; Toogijuku. Meiji Sanju-yo nen Iroha Betsu Dousou Meibo, 1901.

Note: There is one case where we cannot determine whether the graduate was born in Tokyo prefecture or in Saitama prefecture. 


\section{References}

Akinaga Yoshiro. Kikuchi Kuro Den [The History of Kikuchi Kuro]. Aomori: Too Nipposha, 1979.

Aomori-ken. Aomori-ken Shi [The History of Aomori Prefecture] Vol.3 of The Aomoriken Shi. Aomori: Aomori-ken, 1926.

Dore, Ronald. Education in Tokugawa Japan. London: Routledge \& Kegan Paul, 1965.

Ericson, Steven J. The Sound of the Whistle: Railroads and the State on Meiji Japan. Cambridge Mass. \& London: Harvard University Press, 1996.

Hirota Yotsuya. "Kyu Shisan Kaikyu no Botsuraku [Fall of the Former Propertied Class]." In Senryo to Kaikaku [Occupation and Reform], edited by Nakamura Masanori. Tokyo: Iwanami Shoten, 1995.

Hirschumeier, Johhaness, and Yui, Tsunehiko. Development of Japanese Business, 1600 1973. Cambridge, Mass.: Harvard University Press, 1975.

Horimatsu Takekazu, ed. Nippon Kyoiku Shi [History of Japanese Education]. Tokyo: Kokudosha, 1985.

Iai Masahiro. Kazoku Yoran [The Catalogue of Kazoku] Vol.1 of Kazoku Yoran. Tokyo: Iai Masahiro, 1924-1925.

Imuta Toshimitsu. "Kazoku Shisan to Toshi Kodo: Kyu Daimyo no Kabushiki Toshi o Chushin ni [Noble family Assets and Investments: Focusing on the Equity Investment of Former Feudal Lords]." Chiho Kinyu Shi Kenkyu 18, (1987): 1-50.

Ishii Kanji. Kindai Nihon Kinyu Shi Josetsu [Financial History of Modern Japan]. Tokyo: Tokyo Daigaku Shppankai, 1999.

Ishikawa Kenjiro. "Kazoku Shihon to Shizoku Keieisha [Capital of Former Feudal Lord and Managers of Ex-Samurai Class]." In Kogyoka to Kigyosha Katsudo [Industrilization and Entrepreneurial Activities] edited by Yui Tsunehiko. Tokyo: Nihon Keizai Shimbunsha, 1976.

Ito Maki. "Kazoku no Shogai Gakushu to Shogai Hattatsu: Senzen ni okeru Kazoku no Katei Kyoiku ni Chakumoku shite [Lifelong Leaning and Life-span Development of Japanese Nobility: focusing on home education of Japanese nobility].” Gendai Shakai Kenkyuka Kenkyu Hokoku [Research on Contemporary Society] 11, (2015): 27-35.

Jugo Ginko Sonohoka Dome (Mutsu no Kuni Hirosaki Tsugaru Ke Monjyo [Tsugaru Family Archives] at National Institute of Japanese Literature), 1901.

Kanbe Yoshimitsu. "Hangaku kara Meiji no Chu-gakkou heno Renzokusei ni Kansuru Kosatsu [Consideration on Continuity from School of Han to the Junior High School in the Meiji period]." Kokushikan Daigaku Bungakubu Jinbun Gakkai Kiyo [Transactions of the Academic Society of the Humanities] 18, (1986): 1-20. 
Kasumi Kaikan Shoke Shiryo Chosa Iinkai [The Committee for Investigation into Documents of Fromer Kazoku at the Assembly Hall of Former Kazoku] ed. Kazoku Seido Shiryo-shu [Document Collection on Japanese Peerage]. Tokyo: Yoshikawa Kobunkan, 1985.

Keio Gijuku. Keio Gijuku Goju Nen Shi [The 50-Year History of Keio University]. Tokyo: Keio Gijuku, 1907.

Kitahara Kanako. Yogaku Juyo to Chiho no Kindai: Tsugaru Toogijuku o chushin ni [Introducing Western Studies and Modern Regional Area: Focusing on Toogijuku in Tsugaru Region], Tokyo: Iwata Shobo, 2002.

Matsudaira Shuji. "Meiji Shoki Owari Tokugawa-ke no Keizai Kozo [The Structure of the Household Economy of the Tokugawa Family of Owari]." Shakai Keizai Shigaku [Journal of Socio-Economic History Society] 41, no. 5 (1976): 19-40.

Matsuo Masato. Haihan Chiken: Kindai Toitsu Kokka Heno Kumon [The Establishment of Prefectures in Place of Han: Agony towards the Modern Unified State]. Tokyo: Chuokoronsha, 1986.

Miura So. "Meiji-ki ni okeru Kazoku Shihon no Keisei to Kougyoka Toshi: Kyu Iwakuni Hanshu Kikkawa-ke no Tochi-kabushiki Toshi o Jirei to shite [Investment in industrialization and capital formation by a nobleman in the Meiji era: land and share investments of the former Iwakuni Lord Kikkawa]." Rekishi to Keizai 226, (2015): 116.

Morikawa, Hidemasa. Zaibatsu: The Rise and Fall of Family Enterprise Groups in Japan. Tokyo: University of Tokyo Press, 1992.

Nakamura Takafusa. Meiji Taisho Shi [History of Meiji and Taisho Periods] Vol. 1 of Meiji Taisho Shi. Tokyo: Tokyo Daigaku Shuppankai, 2016.

Ochiai Hiroki. Chitsuroku Shobun: Meiji Ishin to Buke no Kaitai [Abolishment of Cash Salary to Ex-Samurai: Meiji Restoration and Dismantling of Ex-Samurai Class]. Tokyo: Chuokoronsha, 2015.

Okubo Toshiaki, ed. Nihon no Shozo: Kyu Kozoku-kazoku Hizo Arubamu [The Photo Album of Former Imperial Family and Nobility] Vol. 2 of Nihon no Shozo. Tokyo: Mainichi Shimbunsha, 1900.

Otabe Yuji. Kazoku: Kindai Nihon Kizoku no Kyozo to Jitsuzo [Kazoku: Images of Noblemen in Modern Japan]. Tokyo: Chuo Koron Shinsha, 2006.

Passin, Herbert. Society and Education in Japan. New York: Bureau of Publications, Teachers College, Columbia University, 1965.

Patrick, Hugh T. "External Equilibrium and Internal Convertibility: Financial policy in Meiji Japan.” Journal of Economic History 25, no. 2 (1965): 187-213. 
Sakai Tatsuro. "Bakumatsu Meiji-Shonen no Hirosaki Han to Keio Gijuku: Edo-nikki o Shiryo to shite [Hirosaki Han and Keio University at the End of the Edo Period and the Early Meiji Period].” Kindai Nihon Kenkyu 10, (1993): 193-242.

Sasamori Seisyuku. Hirosaki Shiritsu Hirosaki Chugaku Toougijuku Enkaku-shi [History of Hirosaki Municipal Hirosaki Junior High School Toogijuku]. Aomori: Hirosaki Shiritsu Hirosaki Chugaku Toougijuku (Iwami Bunko Kyodo Shiryo Collection at Hirosaki City Public Library), 1908.

Sawai Minoru. "Shiryo: Meiji-ki no Okabunushi: Ginko Kaisya Yoroku no Syukei [Material on Major Shareholders in the Meiji Era: Aggregated Data of Bank Company Records].” Osaka Daigaku Keizaigaku [Osaka Economic Papers] 52, no. 4 (2003): 251-280.

Schalow, Thomas R. "Transforming Railroads into Steamships: Banking with the Matsukata family at the 15th Bank', Hitotsubashi Journal of Commerce and Management 22, no. 1 (1987): 55-67.

Smith, Thomas. The Agrarian Origins of Modern Japan. Stanford: Stanford University Press, 1959.

Tamaki, Norio. Japanese Banking: A history, 1859-1959. Cambridge: Cambridge University Press, 1995.

Terao Miho. "Daimyo Kazoku Shihon no Tanjo: Meiji Zen-chu ki no Shimazu-ke no Kabusiki Toshi o Tujite [Origins of Capital Accumulation by Ex-Feudal Lord Peers: Securities Investment by the Shimazu Clan during the Early and Mid-Meiji Period]." Shigaku Zasshi 124, no. 12 (2015): 37-61.

Tipton Jr., Frank B. "Government Policy and Economic Development in Germany and Japan: A Skeptical Tevaluation.” Journal of Economic History 41, no. 1 (1981): 139150.

Toogijuku. Meiji Sanju-yo nen Gun-shi Betsu Dousou Meibo [Alumni Directory by Region]. Aomori (Collection at Toogijuku High School), 1901.

Toogijuku. Meiji Sanju-yo nen Iroha Betsu Dousou Meibo [Alumni Directory by ABC]. Aomori (Collection at Toogijuku High School), 1901.

Tsugaru Tsuguakira Ko Den Kanko-kai, ed. Tsugaru Tsuguakira Ko Den [Biography of Tsugaru Tsuguakira]. Tokyo: Tsugaru Tsuguakira Ko Den Kanko-kai, 1917.

Uchiyama Kazuyuki. Meiji-ki no Kyu-Hanshu-ke to Shakai: Kashizoku to Chiho no Kindaika [Ex-Feudal Lord and Society of Meiji Japan: Peers, Ex-Samurai, and Modernization of a Local Area]. Tokyo: Yoshikawa Kobunkan, 2015.

Yaseki Mon'nosuke. Meiji Chokuyu Chusyaku: Kokumin Hitsudoku [The Emperor's Statements in the Meiji Period]. Tokyo: Kyushundo, 1888. 


\section{Acknowledgements}

We would like to thank Hirosaki City Public Library and Toogijuku High School Library for providing access to the data. This work was supported by the JSPS KAKENHI under Grant number JP15K13027.

\section{Notes}

1 Morikawa, Zaibatsu.

2 Patrick, "External Equilibrium and Internal Convertibility"; Tipton, "Government Policy and Economic Development"; Tamaki, Japanese Banking.

3 Morikawa, Zaibatsu.

4 Tamaki, Japanese Banking.

5 Smith, The Agrarian Origins of Modern Japan.

${ }^{6}$ Hirschmeier and Yui, Development of Japanese Business.

7 Dore, Education in Tokugawa Japan; Passin, Society and Education in Japan.

${ }^{8}$ For detailed information, see Matsuo, Haihan Chiken; Otabe, Kazoku; Ochiai, Chitsuroku Shobun.

9 In addition, koku was an important unit of the main tax, the land tax, during the Tokugawa period and the early Meiji years, and was measured by the volume of rice produced (1 koku was equivalent to about 180.39 litres of rice).

${ }^{10}$ Matsudaira, "Meiji Shoki Owari Tokugawa-ke no Keizai Kozo."

11 Yaseki, Meiji Chokuyu Chusyaku, 33-39.

12 Tsugaru Tsuguakira Koden Kanko-kai, Tsugaru Tsuguakira Ko Den, 336.

13 Ito, "Kazoku no Shogai Gakushu," 28-29.

14 The pronunciation of 'koshaku' for prince and marquis is the same, but their Chinese characters are different.

15 Otabe, Kazoku, 322-360.

16 Otabe, Kazoku, Ch.1.

17 Iai, Kazoku Yoran, 21-42.

18 Ishii, Kindai Nihon Kinyu Shi Josetsu, 499-543.

19 Ericson, The Sound of the Whistle, 104-115; Schalow, "Transforming Railroads into Steamships."

20 These episodes are well known in Japanese business history. See Nakamura, Meiji

Taisho Shi Vol. 1, 334-335.

${ }^{21}$ Ishikawa (1976) indicated the possibility that the equity investments of kazoku gave the newly established companies some credibility, and, therefore, accelerated investments as a whole (Ishikawa, "Kazoku Shihon to Shizoku Keieisha.").

22 Imuta, "Kazoku Shisan to Toshi Kodo."

${ }^{23}$ Uchiyama, Meiji-ki no Kyu-Hanshu-ke to Shakai.

${ }^{24}$ Within the daimyo, 9 of 391 members returned their peerage titles before 1947.

25 Maeda Toshitasu from the largest daimyo family ranked in 17th position among upper-class taxpayers in 1947 when the property tax was introduced in Japan (Hirota, "Kyu Shisan Kaikyu no Botsuraku.").

26 Terao, "Daimyo Kazoku Shihon no Tanjo," 50-54. 
27 Miura, "Meiji-ki ni okeru Kazoku Shihon no Keisei to Kougyoka Toshi," 11-15.

28 Okubo, Nihon no Shozo.

29 According to his biography, he visited the former domain in 1885, 1908, and 1915.

30 Otabe, Kazoku, 97.

31 Before the Meiji period, daimyo had usually protected entertainment, such as sumo wrestling, and Noh traditional masked dance drama (Ito, "Kazoku no Shogai Gakushu," 33). Donations to the kado society might have been such patron activity.

${ }^{32}$ Horimatsu, Nippon Kyoiku Shi, 94.

33 Kanbe, "Hangaku kara Meiji no Chu-gakkou heno Renzokusei ni Kansuru Kosatsu"; Uchiyama, Meiji-ki no Kyu-Hanshu-ke to Shakai.

34 Sakai, "Bakumatsu Meiji-Shonen no Hirosaki Han to Keio Gijuku," 200-209.

35 Fukuzawa had visited the United States and Europe in 1860 and 1862, respectively, as a member of a Japanese embassy to foreign countries.

${ }^{36}$ Keio Gijuku, Keio Gijuku Goju Nen Shi.

37 Aomori-ken, Aomori-ken Shi, 868-869.

38 Tsugaru Tsuguakira Ko Den Kanko-kai, Tsugaru Tsuguakira Ko Den.

39 Akinaga, Kikuchi Kuro Den, 51-64.

40 Too Nippo [Daily Newspaper in Aomori Prefecture], December 22-23, 1900.

41 Tsugaru Tsuguakira Ko Den Kanko-kai, Tsugaru Tsuguakira Ko Den.

${ }^{42}$ Tsugaru Tsuguakira Ko Den Kanko-kai, Tsugaru Tsuguakira Ko Den.

43 Akinaga, Kikuchi Kuro Den.

${ }^{44}$ Kitahara, Yogaku Juyo to Chiho no Kindai. For details of this school, see Kitahara (2002).

45 Akinaga, Kikuchi Kuro Den.

46 Toogijuku, Meiji Sanju-yo nen Gun-shi Betsu Dousou Meibo; Toogijuku, Meiji Sanju-yo nen Iroha Betsu Dousou Meibo.

47 Employees belonged to banks, trading companies, colliery companies, paper companies, cotton spinning companies, printing companies, and so on.

${ }^{48}$ Sasamori, Hirosaki Shiritsu Hirosaki Chugaku Toougijuku Enkaku-shi. 